\title{
Image Gently......
}

\author{
Suraj Agarwal* \\ ${ }^{1}$ Senior lecturer, Guru Govind Singh Dental College, India \\ ${ }^{2}$ Oral \& Maxillofacial Radiologist, Dantika Maxillofacial Telerad Centre, India \\ ${ }^{3}$ Consultant Oral Oncologist, SRL Pathology Lab, India
}

Submission: August 22, 2017; Published: September 15, 2017

*Corresponding author: Suraj Agarwal, Senior lecturer, Guru Govind Singh Dental College, Burhanpur, Oral \& Maxillofacial Radiologist, Dantika Maxillofacial Telerad Centre and Consultant Oral Oncologist, SRL Pathology Lab, Agra, India, Email: dr.surajagarwal@yahoo.in

\section{Short Communication}

As John Dryden said, "He who would search for pearls must dive below".

The dental professional is committed to delivering the highest quality of care to each of its individual patients \& applying advancements in technology and science to continually improve the oral health status of the patient. Radiographs can help the dental practitioner evaluate and definitely diagnose many oral diseases \& conditions. Radiographic examinations can be performed using digital imaging or conventional film. Digital imaging may offer reduced radiation exposure \& the advantage of image analysis that may enhance sensitivity \& reduce error introduced by subjective analysis.

Once a decision to obtain radiographs is made, it is the dentist's responsibility to follow the ALARA Principle (As low as Reasonable Achievable) to minimize the patient's exposure to radiation.

Examples of good radiologic practise include:

a) Use of the fastest image receptor compatible with the radiologic task.

b) Collimation of the beam to the size of the receptor whenever feasible.

c) Proper film exposure \& processing techniques.

d) Use of leaded aprons \& thyroid collars.

Today, ordering a radiograph is in some respects similar to prescribing antibiotics for a patient. Almost any clinician can write a prescription for almost any imaging study, including conventional radiographs (Panoramic, Lateral, Cephalogram, etc.) \& advanced imaging studies (CT, MRI, PET, CBCT). A Patient can go with a prescription from a clinician to most radiology clinics or centers, have the imaging study performed \& then return to the prescribing clinician with copies of the images \& a report from a radiologist interpreting the study.
There are a few questions you should ask yourself before ordering a radiograph or any other imaging study for your patient. They are as follows:

a) What am I looking for in this patient?

b) What are the available imaging studies to evaluate potential disease?

c) Which imaging study do I want?

New Imaging Technologies (like CBCT) have added 3 dimensional capabilities that have many applications in dentistry. Evidence based guidelines \& policies currently are under development by organization associated with radiation control. The usefulness \& future of CBCT have been reviewed with an introduction to issues related to criteria, ramifications \& medicolegal considerations. Certain principles clearly are emerging \& point to need for standards of provisions of care. Because this technology has potential to produce vast amounts of data \& imaging information beyond initial intentions, it is important to interpret all information obtained, including that which may be beyond the immediate diagnostic needs of the practitioner.

Although standards are not officially developed for the use of CBCT, this advancement in maxillofacial dental imaging is an excellent adjunct for improvements in dental care. Dental Radiology Associations globally are in the process of forming regulations which relate to the need for practices of qualified individuals to use of this technology with selection criteria which include clear indications that minimize radiation exposure while maximizing diagnostic information obtained.

Documentary evidence should be provided to demonstrate the diagnostic or treatment guidance need of the CBCT examination. Appropriate demographic, clinical \& case history information should be available to permit the proper 
performance \& interpretation of CBCT Examination \& this information should be provided with the referring prescription. To support the diagnostic necessity of the procedure \& facilitate patient understanding, it is desirable that a separate patient consent be obtained for CBCT procedure before imaging.

Distributed images are a component of the permanent record \& should be stored in a suitable archival format. When using $\mathrm{CBCT}$, the resulting image is required to be supplemented with a written report placed in the patient's records that includes full interpretation of the findings authenticated by a qualified radiologist.

Everything we do in life has some degree of risk. The benefit patients receive from diagnostic dental X- rays far exceeds documented risks, and thus it is our duty as treating surgeons to maximize the benefit for our patients.

\section{Your next submission with Juniper Publishers will reach you the below assets}

- Quality Editorial service

- Swift Peer Review

- Reprints availability

- E-prints Service

- Manuscript Podcast for convenient understanding

- Global attainment for your research

- Manuscript accessibility in different formats

( Pdf, E-pub, Full Text, Audio)

- Unceasing customer service

Track the below URL for one-step submission https://juniperpublishers.com/online-submission.php 